\title{
Editorial
}

\section{My Call was Answered!}

Rachel Dunn, Northumbria University

In my last editorial, I called on more students, from any university, to send their work to the journal. The response to this has been amazing and the journal is expanding to all corners of the globe! This issue shows some of those submissions, and there have been more submitted. The work in this issue showcases the unique work which is being undertaken by students in various universities, and has been a pleasure to read and put together. The diversity doesn't end there: we also have different methods of communicating research in this issue and I hope you enjoy the variety.

There are two articles in this issue. Claudia Man-yiu Tam, from the University of Hong Kong, has written an excellent and engaging piece on the need for animal protection to be included in the school curricula in Hong Kong. It is a fascinating piece, exploring the effect this can have on children later in life, drawing on philosophy and ethics. As an animal law specialist, I thoroughly enjoyed reading this and thank Claudia for introducing me to some new literature!

Jade Potot-Warren, from Northumbria University, has written an excellent article, exploring the Yazidi Massacre, specifically focusing it in the context of the Convention on the Prevention and Punishment of Genocide 1948. It highlights what acts of Genocide actually are and challenges of identifying 'protected groups'. Jade concludes that acts committed by ISIS against the Yazidis satisfy the statutory definition of genocide, and should be recognised as such. A thought-provoking piece, which is very well delivered.

We have three dissertations for you to read. Susan B O'Brien, a student who has completed our LLM Employment Law in Practice, looks at reasonable responses versus proportionality in employee dismissal cases. It is a rigorous and fascinating dissertation, arguing that the 
relationship between reasonableness and proportionality in cases of employer dismissal is not yet fully settled within case law.

Jaxon Hind, a recent graduate of Northumbria University, focused his dissertation on part payment of a debt, promissory estoppel and no oral modification clauses. The recent case of Rock Advertising v MWB Business Exchange Centres [2018] UKSC 24 (SC) considered all of the above mentioned principles, which have been 'developed in a way where one principle is pitted against another'. Jaxon calls for clarity of promissory estoppel and its place next to No Oral Modification Clauses, with the hope that a future Supreme Court decision may resolve ambiguity surrounding the variation of contracts. This is a complex and well analysed dissertation, when there was little academic research already available around the Rock decision.

You may remember Felicity Adams from our previous issue, who published an article exploring the relationship between law and music. She's back! Felicity's dissertation argues that the Feminist Judgments Project represents a valuable approach, which reimagines judicial decision making in line with female interests and reinforces the idea it is a more responsive form of judgement. This is particularly so, Felicity argues, for vulnerable and marginalised women 'whom regularly experience and are subjected to traditional judicial approaches' and uses the feminist re-judgment of $R v$ Dhaliwal [2006] EWCA Crim 1139 for a deeper analysis of this issue. An excellent dissertation, which made me love Lady Hale even more!

As is my tradition in the first issue of the year (it can be a tradition if it has happened twice, right?) we display the highly commended posters from the Poster Conference at Northumbria Law School. This conference includes students from our MLaw and LLB programmes, and the Solicitor Apprenticeship Degree. Many topics are explored, including immigration, knife crime and sex workers. My particular favourite looks at the evolution of sexual offences, using 1950's adverts! Please remember that these are first year students undertaking independent 
research projects, so whilst not everything may be completely correct, it is a huge effort and weeks of work on their part.

Finally, we have a beautiful addition to the journal. For the first time we have a voice recorded conference paper, presented by Mohsen Nagheeby, PhD Candidate, Northumbria University. Mohsen first presented this at our annual staff Christmas Conference, and colleagues thought it was too special to keep to ourselves. Mohsen's thesis focuses on water law and this paper, entitled 'The Ghosts Around the Coasts: Anarchy and Equity in Transboundary River Basins', took him to the Helmand River in Afghanistan. Please do have a listen, it really does take one on a journey.

I would like to end on a note of thanks. Thank you to the staff who have helped me review and source work for this issue. Thank you to the library staff who put all of this together for you to view. And finally, thank you to our students, who put in an enormous amount of work, and have to deal with me, during the review process. This is only possible due to your passions and dedication to your fields.

Enjoy, and I'll see you in the summer! 